\section{Discussion}

We failed to find a record of intra-abdominal granuloma annulare lesions, and this case appears to be the first of visceral granuloma annulare. The relation between diabetes mellitus and generalised granuloma annulare has been a subject of speculation for years but remains unclear. Haim et al reported 13 patients with generalised granuloma annulare, three of whom had overt mild non-insulin dependent diabetes and seven others carbohydrate intolerance after provocative oral prednisolone. ${ }^{3}$ Other studies, however, have not confirmed this observation. A more recent report has suggested an association between granuloma annulare and insulin dependent diabetes. ${ }^{4}$ The relation between diabetes and granuloma annulare is made more complex by the histological appearance of necrobiosis lipoidica diabeticorum, granuloma annulare, and rheumatoid nodules. Each of these conditions includes collagen necrobiosis, and all three variants have been seen in a patient who had insulin dependent diabetes and a sister with rheumatoid arthritis. ${ }^{5}$ The histological similarities among these conditions are so great that they may share the same or a very similar pathogenesis. Immune complex deposition seems the most probable common pathway.

Finally, in our patient there appeared to be a relation between diabetic control and the granuloma annulare. Poor diabetic control $\underline{T}$ was associated with an exacerbation of the lesion, which in turn 3 resulted in excessive working of the ileostomy, which was evident $\stackrel{\mathbb{Q}}{\varrho}$ whatever the cause of his poor diabetic control.

Biopsy sections of the skin and mesenteric nodes showed severa $\widehat{\Omega}$ discrete foci of connective tissue necrosis in the dermis and subcutaneous fat. The zones of necrosis were surrounded by histiocytes showing well marked palisading (figure). The histiocyteक reaction was not strikingly tuberculoid. There were no giant cells, and no evidence of arteritis was detected.

\section{References}

1 Fox TC. Ringed eruption of the fingers. Br $\mathcal{F}$ Dermatol 1895;7:91-5.

2 Muhlbaver JE. Granuloma annulare. $\mathcal{F}$ Am Acad Dermatol 1980;3:217-30.

Haim S, Friedmandiriona diabetes mellitus as revealed in 8 cases. Br $\mathcal{F}$ Dermatol 1970;83:302-5.

4 Muhlemann MF, Williams DR. Granuloma annulare and diabetes mellitus-an association. $B r f \vec{\circ}$ Dermatol $1984 ; 26$ (suppl):12-3.

5 Burton JL. Granuloma annulare, rheumatoid nodules and necrobiosis lipoidica. Br $\mathcal{f}$ Dermatol $\vec{\omega}$ 1977;97:52-4.

(Accepted 22 August 1986)

\title{
Impaired cell mediated immunity in haemophilia in the absence of infection with human immunodeficiency virus
}

\author{
RAJAN MADHOK, \\ A GRACIE \\ G D O LOWE, \\ A BURNETT, \\ K FROEBEL, \\ E FOLLETT, \\ C D FORBES
}

\begin{abstract}
The cell mediated immune response was evaluated in vivo in 29 patients with clinically severe haemophilia by means of the dinitrochlorobenzene skin test. All patients had a response below the median normal value, and in 19 the response was on or below the lower limit of the normal range. There was no difference in skin response between patients positive and negative for the human immunodeficiency virus (HIV; formerly known as human $T$ cell lymphotropic virus III or lymphadenopathy associated virus). In the whole group, and in seronegative patients $(n=17)$, there was aan inverse relation between exposure to clotting factor and skin response. In seropositive patients $(n=12)$ no such association was apparent.
\end{abstract}

This study shows that clotting factor concentrate impairs the cell mediated immune response to a new antigen in the absence of infection with HIV.

\footnotetext{
University Department of Medicine, Glasgow Royal Infirmary, Glasgow G31 2ER

RAJAN MADHOK, MB, MRCP, registrar

A GRACIE, BSC, research assistant

G D O LOWE MD, MRCP, senior lecture

K FROEBEL, PHD, research fellow

C D FORBES, MD, FRCP, reader

Leukaemia Research Fund Laboratory, Department of Haematology, Glasgow Royal Infirmary

A BURNETT, MRCPATH, consultant

Regional Virus Laboratory, Ruchill Hospital, Glasgow

E FOLLETT, PHD, consultant

Correspondence to: Dr Madhok.
}

\section{Introduction}

The acquired immune deficiency syndrome (AIDS) seems to be $\frac{\circ}{\Phi}$ caused by a retrovirus, the human immunodeficiency virus (HIV) (formerly known as human $\mathrm{T}$ lymphotropic virus type III or $\frac{0}{3}$ lymphadenopathy associated virus). ${ }^{12}$ Little is known of the clinical course of infection with HIV, but a range of disease is seen.$^{3}$ It is not known what factors determine progression from the asymptomatic carrier stage to AIDS. Epidemiological data suggest that both the initial infection and its progression to AIDS require additional predisposing or cooperative factors, ${ }^{4-6}$ and both infectious and noninfectious cofactors have been suggested. ${ }^{78}$

Haemophiliacs who have received treatment with lyophilised $\frac{\rho}{3}$ clotting factor concentrate are at increased risk of AIDS. Inverted ratios of $T$ helper to $T$ suppressor lymphocytes have been reported $\frac{}{2}$ in haemophiliacs in the absence of infection with HIV, ${ }^{910}$ and it has $N$ been suggested that HIV is itself an opportunistic pathogen in an already immunocompromised host. ${ }^{911}$ We previously showed that lyophilised factor VIII concentrate in vitro has immunosuppressive properties in tissue cultures of human leucocytes. ${ }^{12}$

The aim of this study was to determine whether haemophiliacs treated with factor concentrates show immunosuppression. The dinitrochlorobenzene skin test is considered to be the best single test to evaluate the cell mediated immune response in vivo ${ }^{1314} \Phi$ and measures a person's ability to respond to a new antigen, $\stackrel{+}{+}$ as dinitrochlorobenzene is rarely encountered. The score on dinitrochlorobenzene testing was compared with exposure to clotting factor and HIV antibody state.

\section{Patients and methods}

We studied 29 patients with clinically severe haemophilia (factor VIII or IX concentration <50U/1) attending the Glasgow adult haemophilia centre, 
including 12 of 15 patients known to be seropositive for antibody to HIV. All patients were examined for features of disease related to HIV. Case records were examined for consumption of clotting factor concentrate over the previous four years, and the mean annual exposure to clotting factor was calculated. The presence of transaminasaemia and previous exposure to hepatitis B virus, as assessed by antigen and antibody testing (Abbott) at routine clinic visits was also noted.

Dinitrochlorobenzene testing-A modified dinitrochlorobenzene test was performed in each case; the method has been described previously. ${ }^{15}$ Briefly, patients were sensitised to dinitrochlorobenzene $(2000 \mu \mathrm{g}$ dissolved in $0 \cdot 1$ $\mathrm{ml}$ acetone) on the dominant forearm. After 14 days the patient was rechallenged with five doses of dinitrochlorobenzene $(30,15,7 \cdot 5,3 \cdot 7$, and $1.8 \mu \mathrm{g})$ on the opposite forearm. The reaction was assessed after 48 hours as follows: 0 no reaction or erythema only; 1 erythema and induration confined to the patch; 2 erythema and induration extending beyond the patch; 3 as for 2 , plus blistering. The maximum possible score was 15 .

Lymphocyte subsets - At the time of rechallenge with dinitrochlorobenzene blood was withdrawn for enumeration of the absolute numbers of $\mathrm{T}$ helper and T suppressor lymphocyte subsets. Mononuclear cells were separated by Ficoll-Hypaque density gradient centrifugation. $T$ lymphocyte subpopulations were measured by indirect immunofluorescence, using monoclonal antibodies to leu- 3 and leu- 2 as phenotypic markers for helper-inducer and suppressor-cytotoxic subsets, respectively, and counted using a cell sorter analyser activated by fluorescein (Becton-Dickinson).

Serological testing-Blood was withdrawn for testing for HIV and screening for viruses including measles, cytomegalovirus, herpes group, and Epstein-Barr virus: IgM antibody was sought. An enzyme linked immunosorbent assay (Abbott) was used to determine HIV antibody state.

Statistical methods-Comparisons between groups were made with the Wilcoxon rank sum test. Associations between variables were assessed with the Spearman rank correlation coefficient. ${ }^{16}$

\section{Results}

Two patients had appreciable cervical lymphadenopathy but no other features of disease related to HIV. One patient had persistent mild thrombocytopenia, the lowest recorded count being $96 \times 10^{9} / 1$. No other patients had clinical features of disease related to HIV.

Serological results-Twelve patients were seropositive for antibody to HIV. No patient had circulating IgM antibody to the other viruses. Previous exposure to hepatitis B virus and the presence of transaminasaemia at clinic visits was similar in the patients positive and negative for HIV (data not shown).

Dinitrochlorobenzene testing_-In a previous study from our area using the same method of dinitrochlorobenzene testing the median score in normal subjects was 9 (range 4-14). ${ }^{15}$ All the patients in the present study had a score below 9 (fig 1 ). The median score in our patients was 3 (range $0-8$ ): this was significantly different from normal $(p<0 \cdot 001)$. In patients positive for HIV the median score was 1 (range $0-8$ ): this was significantly different from normal $(\mathbf{p}<0.001)$. Among the three patients with clinical features of disease related to HIV the score was 0 in the patient with thrombocytopenia and 0 and 4 in the two patients with lymphadenopathy. In seronegative patients the median score was 4 (range $0-8$ ): this was significantly different from normal $(p<0.001)$ but not significantly different from the score in the seropositive patients.

Lymphocyte subsets-The table shows the results. The median number of T helper cells in the patients positive for antibody to HIV was 760 (range: $450-1050$ ) cells $/ \mathrm{mm}^{3}$. This was not significantly different from the number in the patients negative for the antibody (median 800 (range: 300-1670) cells $/ \mathrm{mm}^{3}$ ). The score on dinitrochlorobenzene testing in patients positive for the antibody showed an inverse correlation with the $T$ suppressor cell count $(r=0 \cdot 45)$ but no correlation with the Thelper cell count $(r=0 \cdot 04)$. In

$T$ cell subsets in patients positive and negative for antibody to HIV. Values are medians (ranges)

\begin{tabular}{|c|c|c|c|c|}
\hline & \multicolumn{4}{|c|}{ Score on dinitrochlorobenzene testing } \\
\hline & \multicolumn{2}{|c|}{ Negative for antibody } & \multicolumn{2}{|c|}{ Positive for antibody } \\
\hline & $<4$ & $\geqslant 4$ & $<4$ & $\geqslant 4$ \\
\hline No of patients & 7 & 10 & 9 & 3 \\
\hline T helper cells $\left(\mathrm{mm}^{3}\right)$ & $\begin{array}{l}720 \\
(300-1670)\end{array}$ & $\begin{array}{l}1180^{\star} \\
(740-1650)\end{array}$ & $\begin{array}{l}690 \\
(450-1050)\end{array}$ & $\begin{array}{l}790 \\
(770-900)\end{array}$ \\
\hline $\mathrm{T}$ suppressor cells $\left(/ \mathrm{mm}^{3}\right)$ & $\begin{array}{l}560 \\
(180-1390)\end{array}$ & $\begin{array}{l}800 \\
(480-1100)\end{array}$ & $\begin{array}{l}500 \\
(330-650)\end{array}$ & $\begin{array}{l}480 \\
(370-480)\end{array}$ \\
\hline
\end{tabular}

${ }^{\star} \mathrm{p}<0.05$ (Wilcoxon rank sum test) compared with patients negative for antibody to HIV with score $<4$. patients negative for the antibody the score on dinitrochlorobenzene testing showed a direct correlation $(r=0 \cdot 49)$ with the $T$ helper cell count but no correlation $(r=0 \cdot 15)$ with the $T$ suppressor cell count. The difference in the median number of $T$ helper cells in patients negative for the antibody between those with scores on dinitrochlorobenzene testing in the normal range and those with scores below the normal range was significant $(\mathrm{p}<0.05)$.

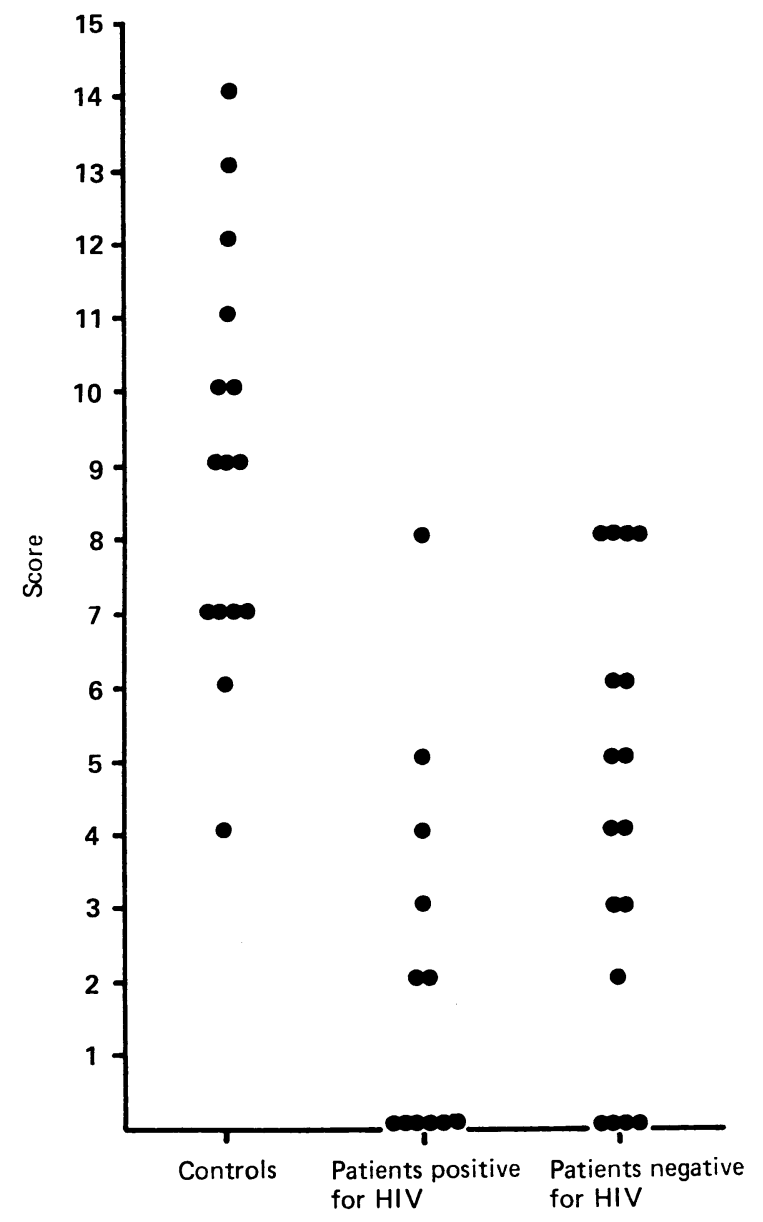

FIG 1-Response (score) to dinitrochlorobenzene in controls and haemophiliacs positive and negative for antibody to HIV.

Consumption of clotting factor-The median annual consumption of clotting factor over four years in all patients was 49608 units (range 5104 190925 ). The median consumption in seropositive patients was 97250 units (range 5104-190925) and in seronegative patients 32375 units (range 9925$92500)$. This difference was not significantly different $(\mathbf{p}<0.05)$. An inverse correlation was noted between increasing usage of clotting factor and decreasing score on dinitrochlorobenzene all patients (fig 2) $(r=-0 \cdot 3$, $\mathrm{p}<0.05$ ). In seronegative patients with a score less than normal $(<4)$ the median consumption of clotting factor was 59685 units (range 21 17592500 ): this was significantly more than that in seronegative patients with a response in the normal range (median 22895 units, range 9925-91925; $\mathrm{p}<0.02$ ). An inverse correlation was noted in all seronegative patients between consumption of clotting factor and score on dinitrochlorobenzene testing $(r=-0.405, p<0.05)$, but the correlation in seropositive patients was not significant $(r=0.08)$; there was no significant difference, however, between the correlations in the seropositive and seronegative groups.

Hepatic dysfunction - There was no significant association between results of dinitrochlorobenzene testing and the presence of transaminasaemia or exposure to hepatitis $B$ virus.

\section{Discussion}

The response to dinitrochlorobenzene evaluates both the afferent and efferent arms of the immune response: it is therefore a measure of a patient's current cell mediated immune state. Our results show 
that all patients with severe haemophilia treated with factor VIII concentrate had a response below the median normal value, and in 19 of the 29 patients studied the response was on or below the lower limit of the normal range (that is, $\leqslant 4$ ). In addition, the response was impaired in patients seronegative for antibody to HIV. This is the first report to show a depressed cell mediated immune response in vivo in haemophiliacs in the absence of antibody to HIV.

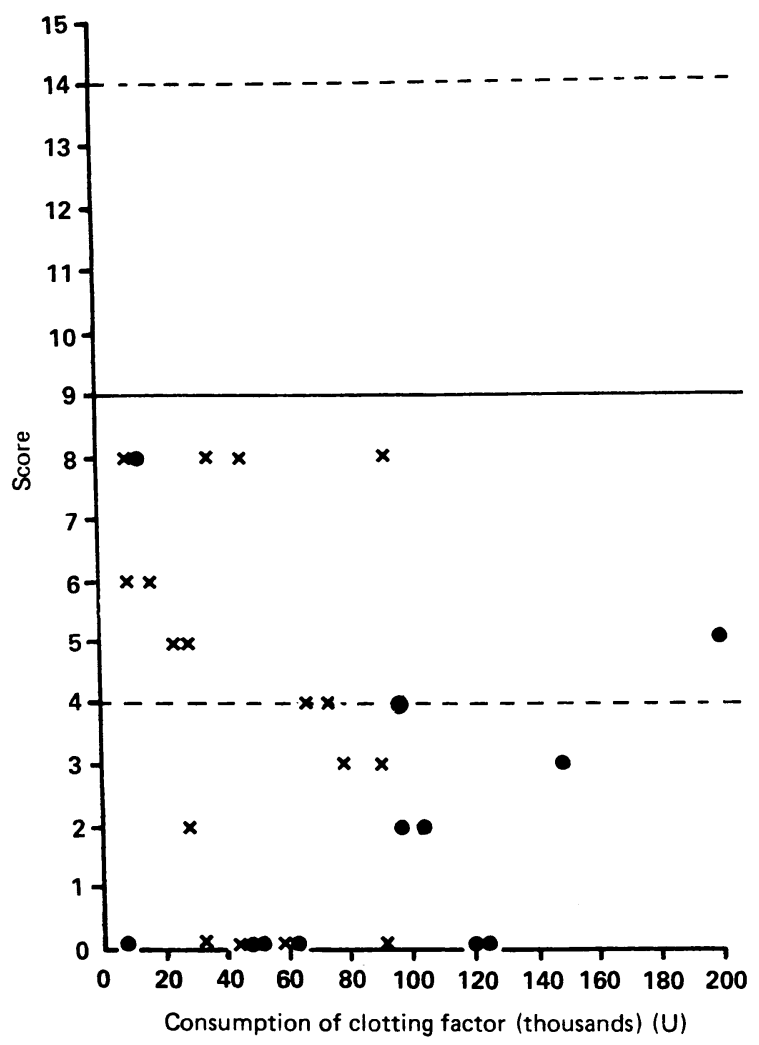

FIG 2-Consumption of clotting factor and score on dinitrochlorobenzene testing in patients positive $(O)$ and negative $(x)$ for antibody to HIV. Broken horizontal lines indicate normal range; solid horizontal line indicates median normal value.

In patients negative for antibody to HIV the response to dinitrochlorobenzene was inversely related to consumption of clotting factor. In particular, patients who had a subnormal response had used significantly more factor concentrate than patients with a response in the normal range. This association of consumption of clotting factor with reduced cell mediated immunity may be due to transmission of viral infection, to a direct chemical effect of concentrate, or to an indirect effect mediated via the immune system.

Concomitant serological studies excluded the possibility of an incidental viral infection. Infection with HIV in the absence of antibody was considered to be unlikely, and no patient in the seronegative group had features of disease related to HIV. In our patient population HIV seroconversion occurred during $1980-4,{ }^{17}$ and in a previous report we showed that seroconversion was associated with use of imported American concentrate. ${ }^{18}$ No further seroconversions were recorded in these patients after 1984, when all patients began to receive locally prepared factor concentrate from an area with a low prevalence of disease related to HIV. In addition, isolates of virus from seronegative patients are exceptional. ${ }^{19} \mathrm{We}$ therefore suggest that the depression in cell mediated immunity is probably due to either a direct effect or an immunological consequence of infusion of factor concentrate.

In a previous study of our patients Forwell et al reported high circulating levels of $\mathrm{FcY}$ receptor antibody. ${ }^{20}$ This antilymphocyte antibody develops after repeated blood transfusions, and its presence correlates directly with survival of renal allografts. ${ }^{21}$ The $\mathrm{FcY}$ receptor is an important immunoregulatory protein, ${ }^{22}$ and blocking of this receptor with antibody or immune complexes stimulates a non-specific $T$ suppressor cell response $e^{23}$ which could additionally inhibit macrophage activation or $\mathrm{T}$ helper function. Excessive activity of $\mathrm{T}$ suppressor cells may therefore account for the abnormalities seen in our seronegative patients on dinitrochlorobenzene testing.

In the 12 seropositive patients the score on dinitrochlorobenzene testing was significantly below normal $(p<0.001)$, and nine of the patients had a score below the normal range. The score did not differ significantly, however, from that in seronegative patients. We could not show a correlation in seropositive patients between the score and consumption of clotting factor. Both these negative findings, however, may have been due to the smaller numbers in this group.

In summary, therefore, our results suggest that cell mediated immunity is decreased in patients with severe haemophilia treated with factor VIII concentrate and that this is related to the amount of factor VIII used. Whether this abnormality is related to risk of infection with HIV or to its sequelae, or both, is not yet known. Though no significant difference in the score on dinitrochlorobenzene testing was observed between seronegative and seropositive patients, infection with HIV in the seropositive patients was fairly recent. Future studies of the response to dinitrochlorobenzene in patients who have had infection with HIV for a longer period may well show lower responses, as immunosuppression induced by HIV may take many years to become firmly established.

This work was supported in part by the Scottish Hospital Endowment Research Trust.

\section{References}

1 Barre-Sinoussi F, Chermann JC, Rey F, et al. Isolation of a T-lymphotropic retrovirus from a patient at risk for the acquired immune deficiency syndrome (AIDS). Science 1984;220:868-71.

2 Gallo RC, Salahuddin SZ, Popovic M, et al. Frequent detection and isolation cytopathic retroviruses (HTLV-III) from patients with AIDS and at risk for AIDS. Science 1984;224: 500-3.

3 Valle SL, Saxinger C, Suni J, et al. Diversity of clinical spectrum of HTLV-III infection. Lancet $1985 ; \mathrm{i}: 301-4$.

4 Shearer G. Acquired immune-deficiency syndrome (AIDS)-a consequence of allogenic Iaantigen recognition. Immunology Today 1983;4:181.

5 Seligman M, Chess L, Fahey JL, et al. AIDS-an immunologic re-evaluation. $N$ Engl 7 Med 1984;311:1286-92.

6 Weiss R. Retroviruses linked with AIDS. Nature 1984;309:12-3.

7 Shearer GM, Levy RB. Non-infectious co-factors in susceptibility to AIDS: possible contributions of semen, HLA alloantigens and lack of natural resistance. Ann NY Acad Sci 1984;437: 49-57.

8 Sonnabend JA, Witkin SS, Purtilo DT. A multifactorial model for the development of AIDS in homosexual men. Ann NY Acad Sci 1984;437:177-83

9 Ludlum CA, Tucker J, Steel CM, et al. Human T-lymphotropic virus infection type III (HTLVIII) infection in seronegative haemophiliacs after transfusion of factor VIII. Lancet 1985;ii: 233-6.

10 Stein SL, Evatt BL, Lawrence JS, et al. Immunologic correlates of infection with HTLV-IIU/LAV in patients with haemophilia. Xth international congress on haemostasis and thrombosis. Thromb Haemost 1985;54:196.

11 Levy JA, Ziegler JL. Acquired immune deficiency syndrome (AIDS) is an opportunistic infection and Kaposi's sarcoma results from secondary immune deficiency stimulation. Lancet 1983;ii: $78-81$.

12 Froebel KS, Madhok R, Forbes CD, et al. Immunological abnormalities in haemophilia: are they caused by imported American factor VIII concentrate? Br Med f 1983;287:1091-3.

13 Aisenberg ACJ. Studies on delayed hypersensitivity in Hodgkins disease. Clin Invest 1962;41 1964-70.

14 Edelman R, Suskind R, Olsen RE, Sirishinha S. Mechanisms of delayed hypersensitivity reaction in children with protein calorie malnutrition. Lancet 1983;i:506-8.

15 Watson MA, Briggs JD, Diamandopoulos AA, et al. Endogenous cell mediated immunity, blood transfusion and outcome of renal transplantation. Lancet 1979;ii:1323-6.

16 Seigel S. Non-parametric statistics for the behavioural sciences. New York: McGraw-Hill, 1956.

17 Madhok R, Melbye M, Forbes CD. Evidence for recent HTLV/III infection in sequentially followed (1974-84) haemophiliacs. Lancet 1985;i:524-5.

18 Melbye M, Froebel KS, Madhok R, et al. HTLV-III seropositivity in European haemophilia exposed to factor VIII concentrate imported from the USA. Lancet 1984;ii:1444-6.

19 Salahuddin SZ, Groopman JE, Markham PD, et al. HTLV-III in symptom-free seronegative persons. Lancet 1984;ii:1418-20.

20 Forwell MA, Briggs JD, Forbes CD, et al. The possible role of immunosuppressive antibodies in acquired immune deficiency. Scott Med f 1984;29:201.

21 Solheim BG, Flatmark A, Halrovsen S, et al. The effect of blood transfusions on renal transplantations: studies of 395 patients registered for transplantation with a cadaveric kidney. Tissue Antigens 1980;16:377-86.

22 Unkeless JC, Fleit H, Mellman IS. Structural aspects and heterogeneity of immunoglobulin Fc receptors. Adv Immuno 1981;31:247-70.

23 Morreta L, Mingari MC, Moretta A, et al. Human T cell lymphocyte sub-populations: studies of the mechanism by which $T$ cells bearing $F c$ receptors for IgG suppress T-dependent $B$ cell differentiation induced by pokeweed mitogen. I Immunol 1979;122:984-90.

(Accepted 8 July 1986) 